\title{
Struktur Sel Sekretori dan Uji Mikroskopi Mikrokimiawi Metabolit Sekunder pada Daun dari Tujuh Taksa Tanaman Obat Antihipertensi
}

\author{
Dwi Lina Nindyawati ${ }^{1)}$, Serafinah Indriyani ${ }^{{ }^{*}}{ }^{*}$ \\ 1) Jurusan Biologi, Fakultas Matematika dan Ilmu Pengetahuan Alam, Universitas Brawijaya \\ ${ }^{*}$ Alamat korenspondensi: indriyani.serafinah04@gmail.com
}

\begin{abstract}
ABSTRAK
Hipertensi merupakan penyakit yang disebabkan oleh meningkatnya tekanan darah. Penggunaan tanaman obat untuk mengatasi hipertensi telah digunakan sejak zaman dahulu. Hal ini dapat terjadi karena di dalam tanaman tersebut mengandung metabolit sekunder yang dimanfaatkan sebagai obat. Penelitian ini bertujuan mengetahui keberadaan senyawa metabolit sekunder, struktur atau bentuk dan kerapatan sel sekretori senyawa metabolit sekunder berupa tanin, flavonoid, dan alkaloid. Sampel yang digunakan adalah daun mimba, belimbing wuluh, seledri, mahkota dewa, sambiloto, sambung nyawa, dan tempuyung (umur 4 bulan). Masing-masing sampel daun diambil tiga ulangan individu tanaman pada daun bagian median. Sampel diiris dengan dua metode irisan yaitu melintang dan paradermal. Irisan melintang dengan clamp on hand microtome dan irisan paradermal dengan preparat whole mount sebanyak tiga ulangan sampel daun. Masing-masing preparat diberi reagen spesifik yaitu tanin dengan potasium dikromat, alkaloid dengan reagen Wagner, dan flavonoid dengan $\mathrm{NaOH} 10 \%$; selanjutnya diamati dengan mikroskop. Sel sekretori pada belimbing wuluh ditemukan berbentuk capitate dan trikoma uniseluler panjang. Trikoma pada sambiloto ditemukan berbentuk kerucut dan juga ditemukan sel litosis. Pada mahkota dewa ditemukan sel idioblas dan pada mimba ditemukan sel trikoma uniseluler panjang dan sel sekretori berbentuk capitate. Pada sambung nyawa ditemukan sel trikoma capitate glandular, sel idioblas, dan sel trikoma multiseluler. Pada seledri dan tempuyung tidak ditemukan bentuk sel sekretori. Tanaman obat yang mengandung ketiga senyawa metabolit sekunder pada daunnya adalah belimbing wuluh, sambiloto, mahkota dewa, dan mimba. Kerapatan sel sekretori yang mengandung flavonoid dan tanin tertinggi yaitu belimbing wuluh berturut-turut sebesar $3,27 \pm 2,46 \mathrm{sel} / \mathrm{mm}^{2}$ dan $3,11 \pm 5,58 \mathrm{sel} / \mathrm{mm}^{2}$ sedangkan sambiloto mengandung alkaloid tertinggi sebesar $1,33 \pm 0,84 \mathrm{sel} / \mathrm{mm}^{2}$.
\end{abstract}

Kata kunci: daun, mikrokimiawi mikroskopi, metabolit sekunder, tanaman obat.

\section{ABSTRACT}

Hypertension is a disease caused by the increasing blood pressure. The use of medicinal plants to overcome hypertension has been used since ancient times because in these plants contain secondary metabolites which can be used as medicine. This study aims to determine the presence of secondary metabolite compounds, their structure or form and the secretory cell density of secondary metabolite compound in the form of tannins, flavonoids, and alkaloids. The sample used are Azadirachta indica A. Juss, Averrhoa bilimbi L., Aphium graveolens L., Phaleria macrocarpa Boerl, Andrographis paniculata Ness., Gynura procumbens (Lour.) Merr., and Sounchus arvensis L.(at age 4 months). Each leaf sample was taken three replicates from the individual plants; it was on the median leaf section. The samples were sliced with two transverse and transverse paradermal methods. Transverse slices had been done by the clamp on hand microtome and paradermal slices had been done by whole-mounted preparations. All of the treatments were conducted in three replicates of leaf samples. Each preparation was given a specific reagent (tannins with potassium dichromate, alkaloids with Wagner and flavonoid reagents with $10 \%$ $\mathrm{NaOH}$ ); then it was observed with a microscope. $A$. bilimbi had secretory cells in the form of the capitate and long unicellular trichomes. A. paniculata had the conical trichomes and lithocyte cells. It was found the idioblast cells in $P$. macrocarpa but in the $A$. indica, it was found a long-trichome cell and capitate shaped-secretory cell. In the G. procumbens, it was found trichome capitae glandular, idioblast cells, and multicellular trichome cells. In addition, there were not found the secretory cells form in A. graveolens and $S$. arvensis. The medicinal plants containing all of the three secondary metabolite compounds in their leaves were $A$.bilimbi, $A$. paniculata, $P$. macrocarpa, and $A$. indica. The density of secretory cells containing the highest flavonoid and tannin was $A$. bilimbi respectively of $3.27 \pm 2.46 \mathrm{cells} / \mathrm{mm}^{2}$ and $3.11 \pm 5.58$ cells $/ \mathrm{mm}^{2}$. A. paniculata showed the highest alkaloid content as $1.33 \pm 0.84 \mathrm{cells} / \mathrm{mm}^{2}$.

Keywords: leaves, secondary metabolites, antihypertension, medicinal plants. 


\section{PENDAHULUAN}

Hipertensi atau darah tinggi adalah suatu penyakit kronis yang sering disebut sebagai silent killer karena pada umumnya seorang pasien tidak mengetahui jika menderita penyakit hipertensi sebelum memeriksakan tekanan darahnya. Penyakit hipertensi merupakan mekanisme meningkatnya tekanan darah sistolik lebih besar dari $140 \mathrm{mmHg}$ atau diastolik lebih besar dari $90 \mathrm{mmHg}$ pada dua kali pengukuran dengan selang waktu 5 menit dalam keadaan cukup istirahat (tenang $)^{[1]}$.

Berdasarkan data di tahun 2013 dengan menggunakan unit analisis individu menunjukkan bahwa secara nasional 25,8\% penduduk Indonesia menderita penyakit hipertensi, jika saat ini penduduk Indonesia sebesar 252.124.458 jiwa maka terdapat 65.048.110 jiwa yang menderita hipertensi. Terdapat 13 provinsi yang persentasenya melebihi angka nasional dan tertinggi di Provinsi Bangka Belitung 30,9\% ${ }^{[2]}$.

Pengobatan hipertensi menggunakan tanaman diketahui dapat memperbaiki organ yang telah mengalami kerusakan akibat penyakit hipertensi. Tanaman obat dapat menurunkan tekanan darah, seperti antara lain diuretikum, antiandrogenik, dan vasodilator. Selama ini pengobatan menggunakan obat-obatan kimiawi sintetik kebanyakan diarahkan hanya untuk menurunkan tekanan darah tanpa mengatasi penyebabnya ${ }^{[3],[4]}$.

Penggunaan tanaman sebagai obat anti hipertensi obat tidak membutuhkan biaya yang mahal, mudah didapatkan dan tidak menyebabkan efek samping seperti pada obat kimiawi sintetik. Kelebihan tanaman obat dalam pengobatan penyakit hipertensi yaitu selain mengobati hipertensi juga dapat mengobati penyakit komplikasi yang disebabkan oleh tekanan darah yang tinggi. Beberapa tanaman yang ada pada masyarakat yang selama ini digunakan dalam pengobatan hipertensi yaitu belimbing wuluh, sambiloto, sambung nyawa, mahkota dewa, mimba, seledri, dan tempuyung ${ }^{[3],[4]}$.

Tanaman obat mengandung banyak senyawa kimia alam yang bermanfaat dalam bidang kesehatan. Senyawa kimia tersebut berupa senyawa metabolit sekunder yang dihasilkan oleh sel sekretori. Sel sekretori merupakan struktur sekresi khusus yang mensekresikan senyawa-senyawa tertentu yang tidak dikeluarkan oleh tubuh tumbuhan.
Golongan senyawa metabolit sekunder yang dapat dimanfaatkan yaitu alkaloid, flavonoid, tanin, steroid, triterpenoid/steroid, saponin, kumarin, glikosida, dan lain sebagainya ${ }^{[5],[6]}$.

Berdasarkan manfaat tanaman obat sebagai anti hipertensi, perlu dilakukan studi untuk mengetahui bentuk atau struktur sel sekretori pada daun tanaman obat dan analisis kualitatif senyawa metabolit sekunder dengan metode mikrokimiawi atau histokimiawi. Lebih lanjut, hasil analisis dapat digunakan sebagai sumber informasi terkait keberadaan flavonoid, tanin, dan alkaloid pada sel sekretori di tanaman obat anti hipertensi.

\section{METODE PENELITIAN}

\section{Lokasi Penelitian}

Pengambilan sampel dilakukan di Balai Tanaman Obat Materia Medika, Kota Batu, Provinsi Jawa Timur. Pengamatan struktur sel sekretori yang mengandung flavonoid, tanin, dan alkaloid dilakukan di Laboratorium Taksonomi Tumbuhan Jurusan Biologi Fakultas Matematika dan Ilmu Pengetahuan Alam, Universitas Brawijaya.

\section{Pengambilan Sampel}

Sampel yang diambil dari Balai Tanaman Obat adalah daun mimba, daun tempuyung, daun mahkota dewa, daun sambiloto, daun beliming wuluh, daun sambung nyawa, dan daun seledri. Pengambilan sampel didokumentasikan dan diambil sebanyak tiga ulangan individu tanaman setiap jenis tanaman yang ditanam dalam polibag untuk satu individu tanaman sehingga terdapat 21 tanaman dalam 21 polibag untuk sampel tanaman. Sampel tanaman yang dipilih berumur sama (4 bulan semaian) dengan perawakan yang sama. Dilakukan perawatan dan penyiraman sebelum dilakukan pembuatan preparat anatomi.

\section{Pembuatan Preparat Anatomi}

Pembuatan preparat anatomi dilakukan dengan metode pengirisan secara melintang dan paradermal dengan metode whole mount. Bagian daun yang dipilih untuk digunakan sebagai preparat yaitu pada daun bagian median tanaman. Pengamatan dilakukan dengan mengiris satu sampel individu daun tanaman obat sebanyak 3 ulangan preparat.

Pembuatan preparat irisan melintang dilakukan dengan penyayatan secara melintang pada masing-masing sampel tanaman dengan menggunakan clamp on hand microtome. Hasil 
sayatan diletakkan pada cawan petri yang berisi akuades untuk mengembangkan jaringan. Hasil sayatan diletakkan di atas slide glass yang telah ditetesi dengan reagen $\mathrm{NaOH} 10 \%$ untuk pengamatan flavonoid, potasium dikromat untuk pengamatan tanin, dan reagen Wagner untuk pengamatan alkaloid ${ }^{[7]}$. Pembuatan reagen Wagner dilakukan dengan mencampurkan iodium dalam kalium iodide ${ }^{[8]}$.

Tahapan pembuatan preparat whole mount (paradermal) adalah sampel daun yang didapatkan dicuci dengan air, difiksasi dengan menggunakan alkohol $70 \%$ dan dicuci dengan akuades. Selanjutnya direndam dengan $\mathrm{HNO}_{3}$ 50\% sampai lunak selama 30 menit dan dibilas dengan akuades. Helai daun dikerik menggunakan silet pada sisi abaksial dan adaksial dan direndam dengan pemutih komersial (bayclin) 50\% selama 30 menit dan dibilas dengan akuades.

\section{Perlakuan Pemberian Reagen}

Spesimen yang telah diiris diletakkan pada slide glass dengan menggunakan pinset kemudian ditetesi dengan reagen spesifik yang digunakan dan ditunggu 2-3 menit. Spesimen dipindahkan ke gelas obyek menggunakan pinset dan kemudian ditetesi dengan reagen spesifiknya. Masing-masing menggunakan $\mathrm{K}_{2} \mathrm{Cr}_{2} \mathrm{O} 7$ untuk deteksi keberadaan tanin, $\mathrm{NaOH}$ $10 \%$ untuk deteksi keberadaan flavonoid, dan asam pikrat untuk deteksi keberadaan alkaloid.

\section{Pengamatan Secara Mikroskopis}

Preparat yang telah siap diamati dengan menggunakan mikroskop binokuler CX 21 dengan perbesaran $100 \mathrm{x}$ dan $400 \mathrm{x}$ dengan pengamatan 3 bidang pandang serta didokumentasikan menggunakan kamera digital. Pengamatan dilakukan dengan melihat adanya perubahan yang terjadi sebelum dan sesudah ditetesi reagen. Kerapatan sel sekretori yang mengandung metabolit sekunder (flavonoid,tanin, dan alkaloid) dihitung dengan menggunakan persamaan sebagai berikut ${ }^{[9]}$ :

\section{Kerapatan \\ selsekretori $=\sum \frac{\text { total sekretori } / n}{\text { Luas bideng pandeng }(\mathrm{mm} 2)}$}

Keterangan:

$\mathrm{n}=$ jumlah bidang pandang per preparat

\section{Analisis Data}

Data yang didapatkan adalah data kualitatif berupa gambar struktur dan bentuk sel sekretori yang mengandung flavonoid, tanin, dan alkaloid. Data kuantitatif berupa kerapatan sel sekretori. Data kuantitatif yang didapatkan dianalisis dengan menggunakan ANOVA dan uji lanjut Mann-Whitney atau uji t dengan $\alpha=5 \%$.

\section{HASIL DAN PEMBAHASAN}

\subsection{Struktur Sel Sekretori pada Tanaman Obat Antihipertensi yangMengandung Flavonoid, Tanin, dan Alkaloid}

\subsubsection{Belimbing Wuluh (Averrhoa bilimbi L.)}

Gambar 1A adalah irisan melintang daun belimbing wuluh yang menunjukkan adanya sel sekretori eksternal berupa trikoma pada bagian epidermis atas (adaksial) dan bawah (abaksial). Terdapat dua jenis trikoma berkelenjar yaitu trikoma yang terdiri atas kepala dan tangkai serta trikoma yang tidak mempunyai kepala berbentuk seperti duri panjang.

Sayatan paradermal daun belimbing wuluh (Gambar 2A) menunjukkan adanya trikoma yang menyebar pada permukaan adaksial dan abaksial daun. Trikoma tersebut tersebar namun paling banyak terdistribusi dekat dengan tulang daun. Bentuk sel sekretori yang ditemukan pada daun belimbing wuluh yaitu trikoma uniseluler panjang, trikoma bentuk capitate berglandula yaitu memiliki tangkai dengan bentuk kepala dan capitate yaitu bentuk seperti kepala $^{[10]}$.

\subsubsection{Sambiloto (Andrographis paniculata} Ness.)

Hasil yang didapat dari irisan melintang daun sambiloto (Gambar 1B) menunjukkan adanya sel sekretori internal dan eksternal. Sel sekretori internal berupa sel litosis yang berbentuk bulat lonjong. Sel sekretori eksternal berupa trikoma berbentuk bulat di bagian epidermis adaksial. Sel litosis tersebut terletak di bagian dekat epidermis, perbedaan dengan sel epidermis dapat dilihat dengan ukuran sel yang lebih besar dibandingkan sel epidermis. Jaringan palisade pada daun sambiloto terdiri atas 1 sampai 2 lapis sel.

Hasil sayatan paradermal daun sambiloto (Gambar 2B) pada permukaan daun menunjukkan adanya trikoma (rambut kelenjar) dan sel litosis. Sel litosis nampak berisi sistolit dan bulu kelenjar tersusun atas 4 sel kepala yang membulat dengan satu sel pangkal berukuran pendek. Bulu non kelenjar tipe uniseriat yang terdiri atas 2 sampai 3 sel. 
Panjang trikoma yang ditemukan pada daun sambiloto ini yaitu hingga $\pm 120 \mu \mathrm{m}$.

Sel litosis pada daun sambiloto dapat dijumpai pada daun bagian adaksial dan abaksial. Sel litosis tersebut berbentuk lonjong seperti bulat telur atau jorong dan mempunyai ukuran yang lebih besar dari pada sel-sel epidermis. Ukuran sel litosis pada bagian adaksial lebih besar dibandingkan dengan bagian abaksial ${ }^{[11]}$.

\subsubsection{Sambung Nyawa (Gynuraprocumbens} (Lour.) Merr.)

Berdasarkan pengamatan pada irisan melintang daun sambung nyawa (Gambar 1C) terdapat adanya sel sekretori eksternal berupa trikoma non kelenjar dan sel sekretori yang terdapat pada epidermis. Bulu kelenjar tersebut nampak pada bagian abaksial dan adaksial. Jaringan palisade terdiri atas 1- 2 lapis sel. Trikoma non kelenjar nampak tersusun atas beberapa sel.

Hasil pengamatan pada sayatan paradermal (Gambar 2C) menunjukkan trikoma yang tersebar pada permukaan daun bagian adaksial dan abaksial. Trikoma non kelenjar ini terdistribusi secara merata pada permukaan daun. Trikoma tersebut berbentuk lancip pada ujungnya dan terdiri atas 4 hingga 6 sel.

Bentuk trikoma berglandular yang ditemukan pada daun sambung nyawa adalah capitate. Bentuk trikoma capitate yang terdiri atas satu sel basal, terdiri atas 2 hingga 4 sel batang atau tangkai dan terbentuk seperti sel kepala tunggal. Selain itu juga ditemukan trikoma non glandular yang terdiri atas 3 hingga $4 \mathrm{sel}^{[10]}$.

\subsubsection{Mimba (Azadirachta indica A. Juss )}

Hasil pengamatan terhadap irisan melintang daun mimba (Gambar 1D) menunjukkan adanya sel sekretori internal yang merupakan diferensiasi dari jaringan epidermis. Sel sekretori tersebut nampak berada pada permukaan daun bagian adaksial dan abaksial. Sel sekretori tersebut memiliki bentuk dan ukuran yang hampir sama namun lebih besar dibandingkan dengan sel- sel epidermis.

Hasil pengamatan irisan melintang menunjukkan selain ditemukan sel seketori yang merupakan diferensiasi dari sel epidermis juga ditemukan sel sekretori eksternal berbentuk bulat jorong dan terlihat menonjol pada lapisan epidermis adaksial (Gambar 1D.c). Jaringan palisade pada daun mimba bersifat bifasial karena jaringan palisade hanya ditemukan pada salah satu sisi daun saja.

Hasil sayatan paradermal (Gambar2D) menunjukkan adanya trikoma uniseluler dan sel sekretori nampak berbentuk bulat pipih. Trikoma yang ditemukan berbentuk seperti kail dengan ujung yang meruncing, sedangkan sel sekretoriyang berbentuk bulat pipih nampak berukuran 10x lebih besar dibandingkan dengan sel lain yang ada pada permukaan daun. Adanya trikoma dan sel sekretori pada daun mimba terdistribusi secara merata antara bagian adaksial dan abaksial daun.

\subsubsection{Mahkota dewa (Phaleria macrocarpa Boerl) \\ Hasil pengamatan terhadap irisan} melintang daun mahkota dewa (Gambar 1E) menunjukkan adanya sel sekretori internal yang merupakan diferensiasi dari jaringan epidermis. Sel sekretori tersebut nampak berada pada permukaan daun bagian adaksial, memiliki bentuk dan ukuran yang hampir sama namun lebih besar dibandingkan dengan sel-sel pada epidermis.

Hasil sayatan paradermal (Gambar 2E) menunjukkan adanya sel sekretori berbentuk bulatan-bulatan kecil dan sel sekretori berbentuk lonjong. Sel sekretori berbentuk bulat kecil yang tersebar di bagian adaksial daun mahkota dewa.

Sel sekretori yang berbentuk bulat pipih nampak berukuran $5 x$ lebih besar dibandingkan dengan sel sekretori yang berbentuk bulat kecil pada permukaan daun (Gambar 2E.c). Adanya trikoma dan sel sekretori pada daun mahkota dewa terdistribusi secara merata antara bagian adaksial dan abaksial daun.

\subsubsection{Seledri (Apium graveolens L.) dan Tempuyung (Sonchus arvensis L.)}

Hasil pengamatan pada irisan melintang daun seledri (Gambar 1F) dan daun tempuyung (Gambar 1G), tidak ditemukan adanya sel sekretori yang mengandung tanin, alkaloid, dan flavonoid pada bagian epidermis, jaringan palisade maupun pada berkas pengangkut. Hasil sayatan paradermal keduanya baik adaksial maupun abaksial juga tidak ditemukan adanya sel sekretori yang mengandung metabolit sekunder. 


\subsection{Hasil Uji Mikroskopi Mikrokimiawi dari Tanaman Obat Antihipertensi}

4.2.1 Belimbing Wuluh (Averrhoa bilimbi L.) Pengamatan pada sayatan paradermal (Gambar 2A) menunjukkan bahwa sel trikoma yang mengandung flavonoid dapat diketahui dari perubahan warna trikoma menjadi kuning cera. Trikoma yang mengandung tanin menjadi orange sedangkan yang mengandung alkaloid terjadi perubahan menjadi kuning.

\subsubsection{Sambiloto (Andrographis paniculata Ness.)}

Hasil sayatan paradermal (Gambar 2B) menunjukkan, pada trikoma peltate scale yang mengandung flavonoid yaitu bentuk trikoma kerucut uniseluler dengan bagian ujung yang lebar dan sel sekretori multiseluler yangberubah menjadi kuning, sedangkan yang mengandung tanin mengalami perubahan warna menjadi orange. Trikoma yang mengandung alkaloid terjadi perubahan warna menjadi coklat kekuningan dan sel litosis yang mengandung flavonoid menunjukkan perubahan warna menjadi hijau kekuningan.

\subsubsection{Sambung Nyawa (Gynura procumbens (Lour.) Merr.) \\ Trikoma yang mengandung flavonoid} mengalami perubahan warna menjadi kuning hingga kuning tua sedangkan yang mengandung tanin mengalami perubahan warna menjadi coklat dan trikoma yang mengandung alkaloid mengalami perubahan warna menjadi coklat kekuningan.

Trikoma yang mengandung flavonoid tidak semua ada pada bagian sel dari trikoma. Terdapat flavonoid pada semua bagian sel trikoma (Gambar 2C.a) sedangkan yang lain hanya pada bagian ujung dan tengah (Gambar 2 C.b). Trikoma yang mengandung tanin nampak pada bagian sel dekat dengan pangkal trikoma, berubah warna menjadi coklat. Alkaloid teramati pada sel yang dekat dengan ujung dan pangkal trikoma yang berubah warna menjadi coklat kekuningan. Trikoma yang mengandung alkaloid merupakan bentuk trikoma yang berkelenjar karena mempunyai bagian kepala pada ujung trikoma.

\subsubsection{Mimba (Azadirachta indica A. Juss )}

Sayatan paradermal (Gambar 2D) menunjukkan bahwa sel sekretori yang mengandung flavonoid nampak berwarna kuning. Sel sekretori yang mengandung tanin nampak berwarna coklat dan sel sekretori yang mengandung alkaloid nampak berwarna coklat kekuningan.

Sel sekretori yang mengandung flavonoid banyak terdistribusi pada bagian abaksial dan adaksial daun. Sel sekretori yang mengandung flavonoid pada irisan melintang nampak lebih rapat dibandingkan dengan sel sekretori yang positif mengandung tanin dan alkaloid.

\subsubsection{Mahkota dewa (Phaleria macrocarpa Boerl)}

Sel sekretori yang mengandung flavonoid pada sayatan melintang (Gambar 1E) menunjukkan perubahan warna menjadi kuning sedangkan yang mengandung tanin mengalami perubahan warna menjadi orange dan mengandung alkaloid terjadi perubahan warna menjadi coklat kekuningan. Keberadaan flavonoid, pada sayatan paradermal (Gambar 2E) ditunjukkan dengan perubahan warna menjadi kuning pekat sedangkan pada sel sekretori yang mengandung tanin terjadi perubahan menjadi orange dan sel sekretori yang mengandung alkaloid nampak berwana kuning terang.

\subsubsection{Seledri (Apium graveolens L.) dan Tempuyung (Sonchus arvensis L.) \\ Hasil pengamatan dengan irisan} melintang daun seledri (Gambar 1F) dan daun tempuyung (Gambar 1G) menunjukkan hasil negatif (tidak mengandung metabolit sekunder). Setelah diberikan reagen spesifik untuk mendeteksi keberadaan tanin, flvonoid, dan alkaloid tidak menunjukkan adanya perubahan warna yang terjadi. Tidak ditemukan adanya sel sekretori yang mengandung tanin, alkaloid, dan flavonoid pada bagian epidermis, jaringan palisade maupun pada berkas pengangkut irisan melintang daun seledri.

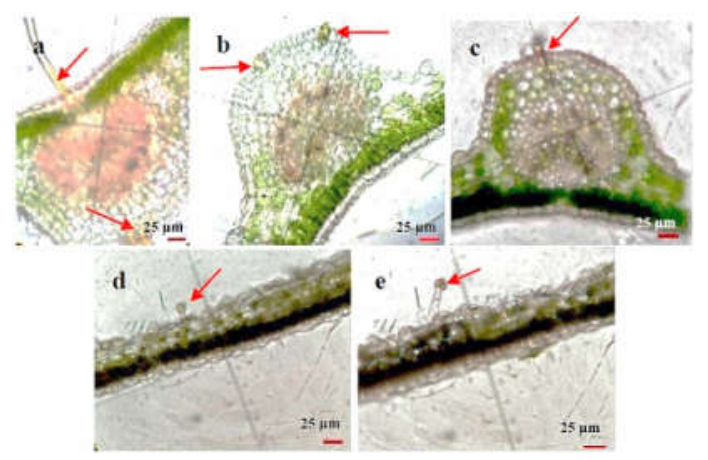

A. Daun belimbing wuluh. Keterangan:(a) trikoma mengandung flavonoid, (b) trikoma mengandung tanin, (c) trikoma tanpa mengandung metabolit sekunder, (d) sekretori internal mengandung tanin, (e) trikoma mengandung tannin. 


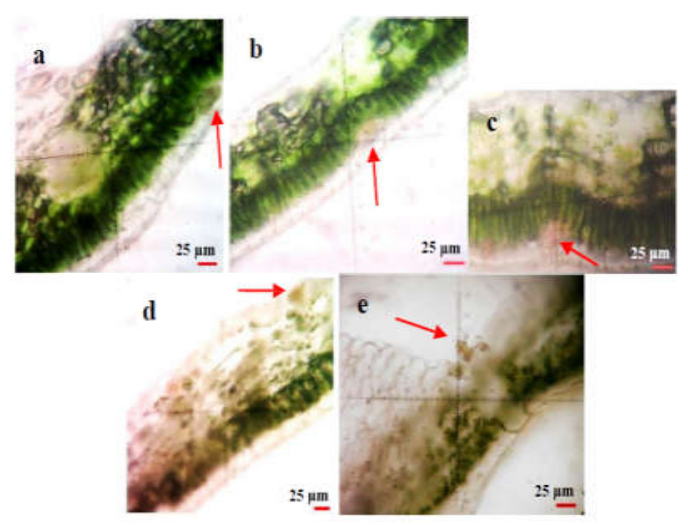

B. D aun sambiloto. Keterangan: (a)sel litosis mengandung flavonoid, (b) sel litosis mengandung flavonoid, (c) sellitosis mengandung tanin, (d) sekretori mengandung alkaloid, (e) sel sekretori mengandung alkaloid.

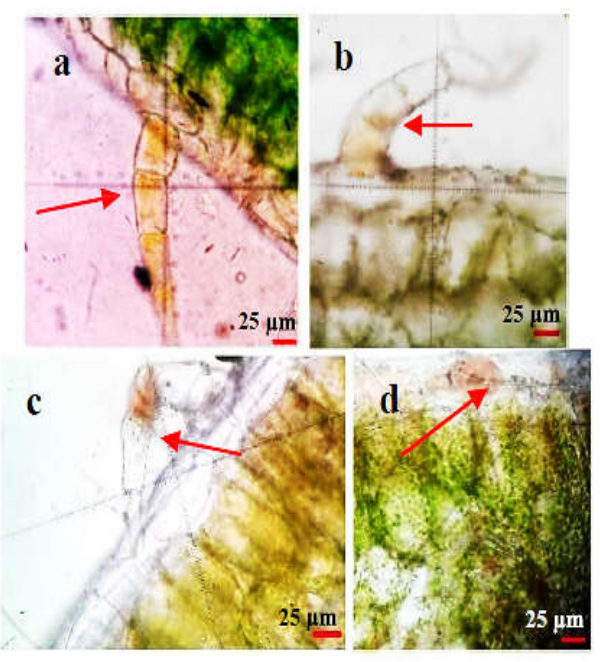

C. Daun sambung nyawa Keterangan:(a) trikoma mengandung flavonoid, (b) trikoma mengandung alkaloid, (c,d) trikoma mengandung tanin.
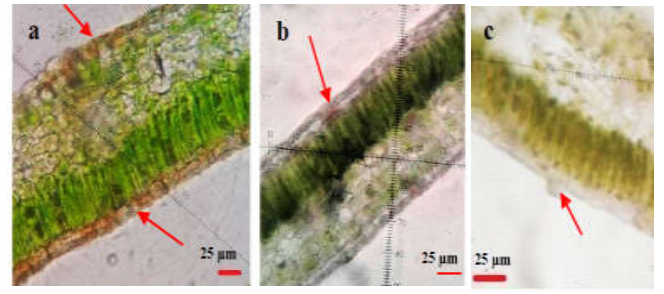

D. Daun mimba. Keterangan : (a) trikoma mangadung flavonoid, (b) trikoma mengandung tanin, (c) trikoma mengandung alkaloid.

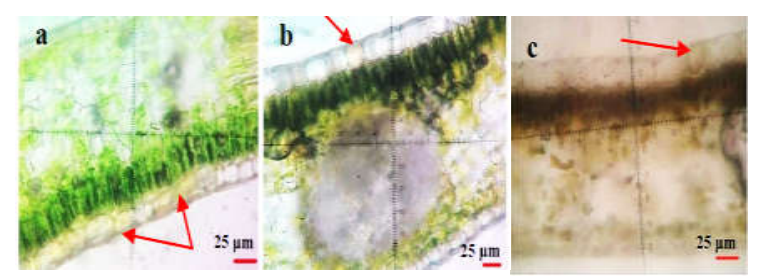

E. Daun mahkota dewa. Keterangan:(a) sel sekretori mangandung flavonoid, (b) sel sekretori mengandung tanin, (c) sel sekretori mengandung alkaloid.

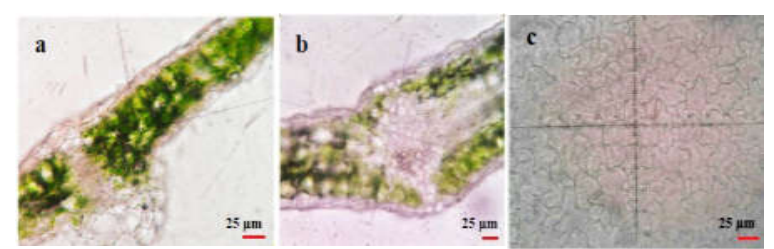

F. Daun seledri. Keterangan:(a,b,c) tidak mengandung senyawa metabolit sekunder (tanin,

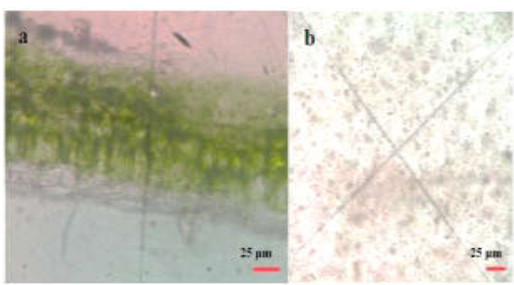

G. Daun tempuyung. Keterangan: (a) tidak mengandung senyawa metabolit sekunder, irisan melintang (b) tidak mengandung senyawa metabolit sekunder, sayatan paradermal.

Gambar 1. Struktur sel sekretori pada daun dengan irisan melintang. Tanda panah menunjukkan sel sekretori yang mengandung metabolit sekunder (flavonoid, tanin, alkaloid).

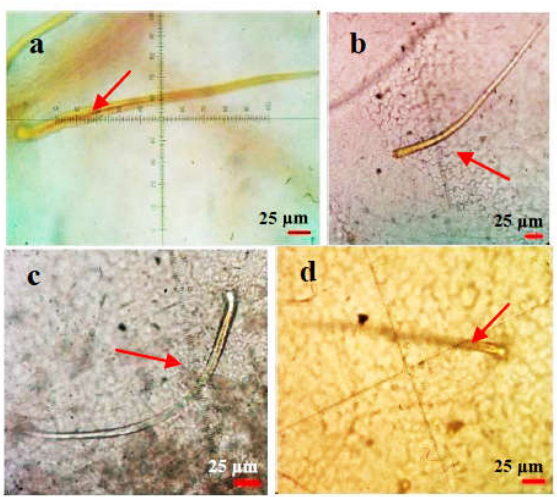

A. Daun belimbing wuluh. Keterangan : (a) trikoma mengandung flavonoid, (b) trikoma mengandung flavonoid, (c) trikoma mengandung alkaloid, (d) trikoma mengandung tanin.
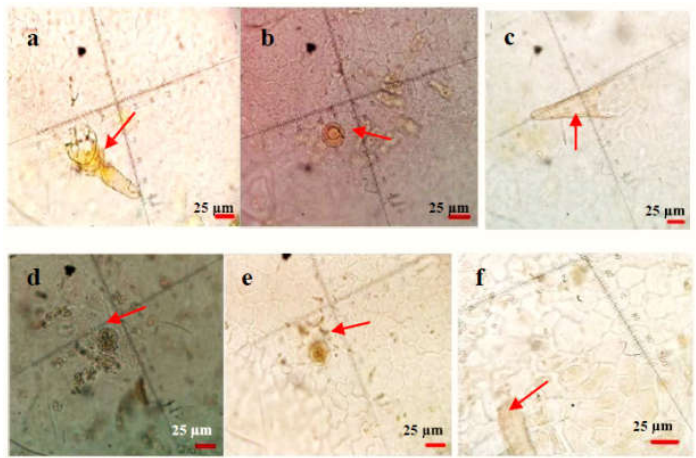

B. Daun sambiloto dengan. Keterangan:(a) bulu kelenjar mengandung flavonoid, (b) sel sekretori mengandung flavonoid, (c) bulu kelenjar mengandung flavonoid, (d) sel sekretori mengandung tanin, e) sel sekretori mengandung alkaloid, f) sel litosis mengandung alkaloid. 


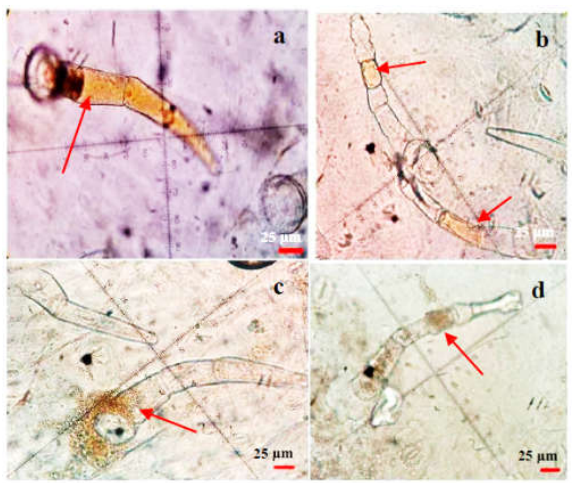

C. Daun sambung nyawa. Keterangan:(a,b) trikoma mengandung flavonoid, (c) trikoma mengandung tanin, (d) trikoma mengandung alkaloid.
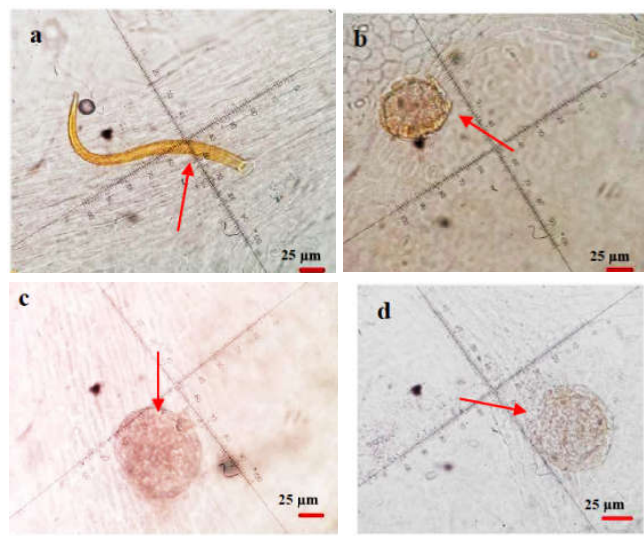

D. Daun mimba. Keterangan : (a) trikoma mengandung flavonoid, (b) sel sekretori mengandung tanin, (c) sel sekretori mengandung tanin, (d) sel sekretori mengandung alkaloid.

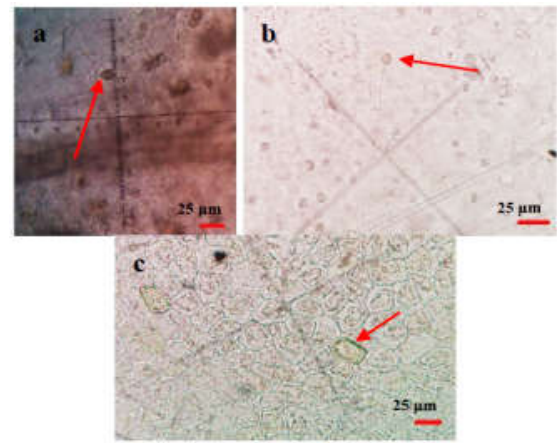

E. Daun mahkota dewa. Keterangan:(a) sel sekretori mangandung flavonoid, (b) sel sekretori mengandung tanin, (c) sel sekretori mengandung alkaloid.

Gambar 2. Struktur sel sekretori pada daun dengan sayatan paradermal. Tanda panah menunjukkan sel sekretori yang mengandung metabolit sekunder (flavonoid, tanin, alkaloid).

\subsection{Kerapatan Sel Sekretori yang Mengandung Tanin, Alkaloid, dan Flavonoid pada Tanaman Obat Antihipertensi}

\subsubsection{Kerapatan Sel Sekretori Mengandung Flavonoid}

Hasil perhitungan kerapatan sel sekretori pada daun yang mengandung flavonoid menunjukkan kerapatan sel sekretori tertinggi yaitu pada daun belimbing wuluh $(3,27 \pm 2,46$ $\mathrm{sel} / \mathrm{mm}^{2}$ ) yang berbeda dengan mahkota dewa $\left(0,38 \pm 1,14 \quad \mathrm{sel} / \mathrm{mm}^{2}\right)$, sambung nyawa $\left(1,27 \pm 1,40 \quad \mathrm{sel} / \mathrm{mm}^{2}\right), \quad$ dan $\operatorname{mimba}\left(0,5 \pm 0,51 \mathrm{sel} / \mathrm{mm}^{2}\right)$. Kerapatan sel sekretori yang mengandung flavonoid terendah pada daun seledri dan tempuyung $(0,00 \pm 0,00$ $\mathrm{sel} / \mathrm{mm}^{2}$ ) berbeda nyata dengan daun sambiloto $\left(2,88 \pm 1,60 \mathrm{sel} / \mathrm{mm}^{2}\right)$, mahkota dewa $(0,38 \pm 1,14$ $\left.\mathrm{sel} / \mathrm{mm}^{2}\right)$, sambung nyawa $\left(1,27 \pm 1,40 \mathrm{sel} / \mathrm{mm}^{2}\right)$, belimbing wuluh $\left(3,27 \pm 2,46 \mathrm{sel} / \mathrm{mm}^{2}\right)$ dan mimba $\left(0,5 \pm 0,51 \mathrm{sel} / \mathrm{mm}^{2}\right)$. Daun seledri dan tempuyung menunjukkan tidak mengandung kerapatan sel yang mengandung flavonoid (Gambar 3).

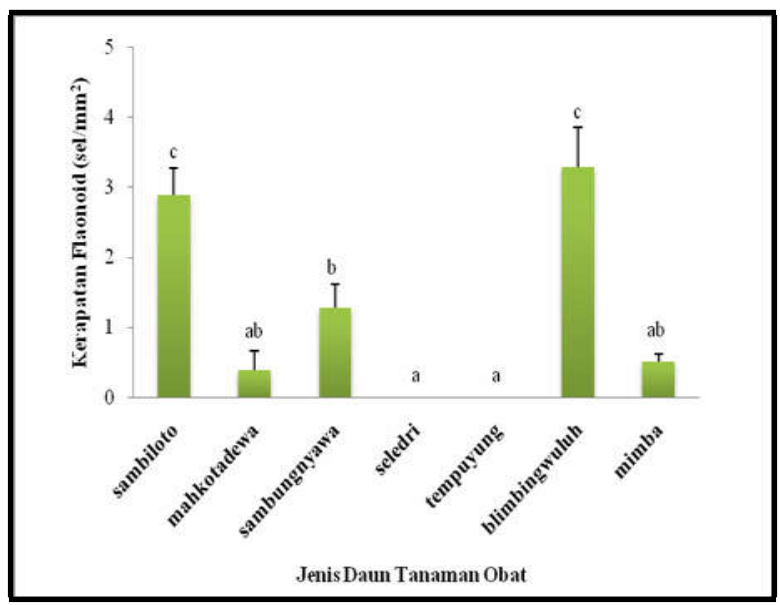

Gambar 3. Kerapatan selsekretoriyang mengandung flavonoid pada tanaman obat antihipertensi. Notasi yang sama menunjukkan tidak berbeda nyata berdasarkan Uji Mann- Whitney $\alpha=0,05$

\subsubsection{Kerapatan Sel Sekretori Mengandung Tanin \\ Hasil perhitungan kerapatan sel} sekretori yang mengandung tanin menunjukkan kerapatan sel sekretori tertinggi yaitu pada daun belimbing wuluh $\left(3,11 \pm 5,58 \mathrm{sel} / \mathrm{mm}^{2}\right)$ yang berbeda nyata dengan daun mahkota dewa $(0,05$ $\left.\pm 0,23 \mathrm{sel} / \mathrm{mm}^{2}\right)$, seledri $\left(0,00 \pm 0,00 \mathrm{sel} / \mathrm{mm}^{2}\right)$, tempuyung $\left(0,00 \pm 0,00 \mathrm{sel} / \mathrm{mm}^{2}\right)$, dan mimba $\left(0,05 \pm 0,23 \mathrm{sel} / \mathrm{mm}^{2}\right)$. Kerapatan sel sekretori 
yang mengandung tannin terendah pada daun seledri dan tempuyung $\left(0,00 \pm 0,00 \mathrm{sel} / \mathrm{mm}^{2}\right)$ berbeda nyata dengan daun sambung nyawa $\left(1,27 \pm 1,40 \mathrm{sel} / \mathrm{mm}^{2}\right)$, dan belimbing wuluh $(3,27$ $\pm 2,46 \mathrm{sel} / \mathrm{mm}^{2}$ ). Daun seledri dan tempuyung menunjukkan tidak mengandung kerapatan sel yang mengandung tannin (Gambar 4).

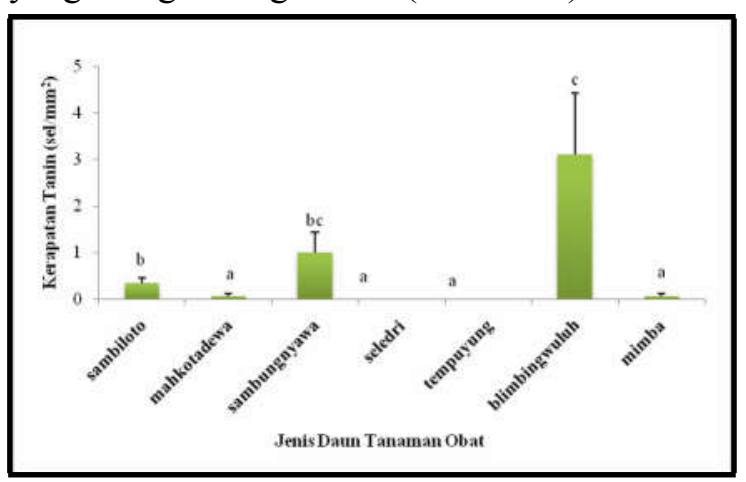

Gambar 4.Kerapatan sel sekretori yang mengandung tannin pada tanaman obat antihipertensi. Notasi yang sama menunjukkan tidak berbeda nyata berdasarkan uji $\mathrm{t}$

\subsubsection{Kerapatan Sel Sekretori Mengandung Alkaloid}

Hasil perhitungan kerapatan sel sekretori yang mengandung alkaloid menunjukkan kerapatan sel sekretori tertinggi yaitu pada daun sambiloto $\left(1,33 \pm 0,84 \mathrm{sel} / \mathrm{mm}^{2}\right)$ yang berbeda dengan daun mahkota dewa $\left(0,16 \pm 0,38 \mathrm{sel} / \mathrm{mm}^{2}\right)$, sambung nyawa $\left(0,00 \pm 0,00 \mathrm{sel} / \mathrm{mm}^{2}\right)$, seledri $\left(0,00 \pm 0,00 \mathrm{sel} / \mathrm{mm}^{2}\right)$, tempuyung $(0,00 \pm 0,00$ $\left.\mathrm{sel} / \mathrm{mm}^{2}\right)$, dan mimba $\left(0,11 \pm 0,32 \mathrm{sel} / \mathrm{mm}^{2}\right)$. Kerapatan sel sekretori yang mengandung tannin terendah pada daun seledri dan tempuyung $\left(0,00 \pm 0,00 \mathrm{sel} / \mathrm{mm}^{2}\right)$. Daun seledri, sambung nyawa dan tempuyung menunjukkan tidak mengandung kerapatan sel yang mengandung tannin [Gambar 5].

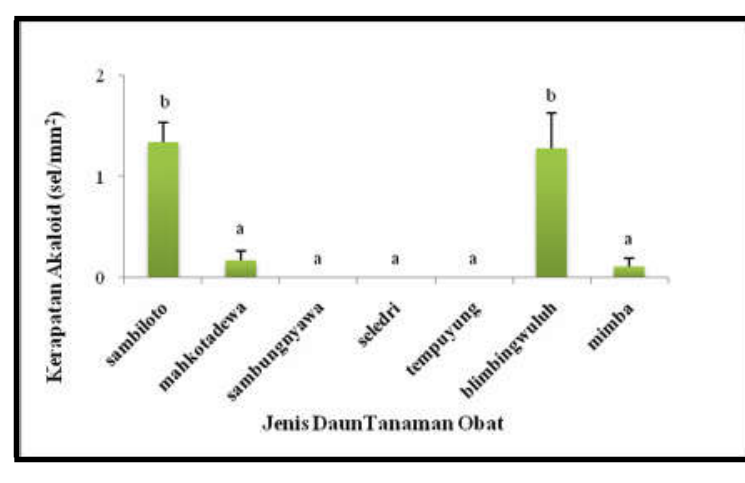

Gambar 5. Kerapatan sel sekretori yang mengandung alkaloid pada tanaman obat antihipertensi. Notasi yang sama menunjukkan tidak berbeda nyata berdasarkan UjiMann- Whitney $\alpha=0,05$.

\section{KESIMPULAN}

Berdasarkan hasil uji mikroskopi mikrokimiawi didapatkan kesimpulan sebagai berikut:

1. Struktur sekretori yang ditemukan dalam penelitian ini yaitu pada sampel daun belimbing wuluh ditemukan sel sekretori berbentuk capitate glandular dan non glandular serta trikoma uniselulerpanjang. Daun sambiloto ditemukan trikoma bentuk kerucut, sel litosis, dan trikoma non kelenjar uniseriat. Daun mahkota dewa ditemukan sel berbentuk lonjong yang tersebar pada jaringan epidermis (sel idioblas). Daun mimba ditemukan sel trikoma uniseluler panjang dan sel sekretori bulat pipih besar. Sampel daunsambung nyawa ditemukan sel trikoma capitate glandular, sel idioblas di epidermis, dan sel trikoma multiseluler. Sampel daun seledri dan tempuyung tidak ditemukan sel sekretori.

2. Tanaman obat yang mengandung ketiga senyawa (flavonoid, tanin, dan alkaloid) pada daunnya adalah belimbing wuluh, sambiloto, mahkota dewa, dan mimba. Tanaman obat yang mengandung dua senyawa (alkaloid dan flavonoid) pada daunnya adalah sambung nyawa. Tanaman obat yang tidak mengandung ketiga senyawa (tanin, alkaloid, dan flavonoid) pada daunnya adalah seledri dan tempuyung.

3. Kerapatan sel sekretori yang mengandung flavonoid dan tanin paling tinggi yaitu daun belimbing wuluh masing-masing $3,27 \pm 2,46 \mathrm{sel} / \mathrm{mm}^{2}$ dan $3,11 \pm 5,58 \mathrm{sel} / \mathrm{mm}^{2}$ sedangkan kerapatan sel sekretori yang paling tinggi mengandung alkaloid adalah daun sambiloto yaitu1,33 $\pm 0,84 \mathrm{sel} / \mathrm{mm}^{2}$.

\section{DAFTAR PUSTAKA}

[1] DepkesRI. 2012a. Hipertensi Penyebab Kematian Nomor Tiga. Diunduh pada tangga 13 September 2015 melalui www.depkes.go.id.

[2] Rikesdas. 2013. Hasil Riset Kesehatan Dasar2013. Diunduh 5 September 2015 melalui http://www.depkes.go.id.

[3] Depkes. 2012b. Pengobatan Komplementer Tradisional Alternatif. 
Diunduh pada tangga 13 September 2012 melalui http://buk.depkes.go.id/.

[4] LIPI. 2009. Pengobatan Alternatif Dengan Tanaman Obat. Diunduh pada tanggal 3 September 2012 melalui www.lipi.go.id.

[5] Barnes, J. Anderson,L. \& Phillipson, J. 2005. Herbal Medicine. Second edition. Pharmaceutical Press. USA.

[6] Redha, A. 2010. Flavonoid: Struktur, Sifat Antioksidatif Dan Peranannya Dalam Sistem Biologis. Jurnal Belian Vol. 9 No. 2. Hal $196-202$.

[7] Mulyani, S. \& L. Toga. 2011. Analisis flavonoid dan tanin dengan metode mikroskopi mikrokimiawi. Majalah Obat Tradisional. Yogyakarta.

[8] Afiyati\& Mimiek, M. 2013. The Effect Of Fraction Containing Alkaloids of
Hibiscus Lower(Hibiscus rosa-sinensis L.)Red Variety ToMucolytic Activities In Vitro. Trad. Med. J.vol. 18(3), p 187194.

[9] Novita, M.D.A. 2013. Kerapatan dan Bentuk Kristal Kalsium Oksalat Umbi Porang (Amorphophallus muelleri Blume) Pada Fase Pertengahan Pertumbuhan Hasil Penanaman Dengan Perlakuan Pupuk P dan K. Jurusan Biologi Fakultas Matematika dan Ilmu Pengetahuan Alam. Universitas Brawijaya. Malang.Skripsi.

[10] Qi Lu\& Feng Liu Ji. 2012. Structure And Hictochemistry of The Glandular Trichomes On The Leaves Of Isodon rubescens. African Journal of Biotechnology. Vol 11. No 17.

[11] Dorly. 2006. Struktur Sekretori Tanaman Bahan Ramuan Obat Diabetes. Jurnal II Pertanian Indonesia. Vol11. No.1. 